\title{
Egg distribution, bottom topography and small-scale cod population structure in a coastal marine system
}

\author{
Halvor Knutsen ${ }^{1,2, *}$, Esben Moland Olsen ${ }^{1,2}$, Lorenzo Ciannelli ${ }^{2,4}$, \\ Sigurd Heiberg Espeland ${ }^{2}$, Jan Atle Knutsen ${ }^{1}$, Jan Henrik Simonsen ${ }^{1}$, \\ Stig Skreslet ${ }^{3}$, Nils Chr. Stenseth ${ }^{1,2}$ \\ ${ }^{1}$ Institute of Marine Research, Flødevigen, 4817 His, Norway \\ ${ }^{2}$ Centre for Ecological and Evolutionary Synthesis (CEES), University of Oslo, PO Box 1066, Blindern, 0316 Oslo, Norway \\ ${ }^{3}$ Bodø University College, Department of Fisheries and Natural Sciences, 8049 Bodø, Norway \\ ${ }^{4}$ Present address: College of Oceanic and Atmospheric Sciences, Oregon State University, Corvallis, Oregon 97331, USA
}

\begin{abstract}
Coastal marine species with pelagic egg and larval stages, such as the Atlantic cod Gadus morhua, can be structured into genetically distinct local populations on a surprisingly small geographic scale considering their dispersal potential. Mechanisms responsible for such small-scale genetic structure may involve homing of adults to their natal spawning grounds, but also local retention of pelagic eggs and larvae. For example, spawning within sheltered fjord habitats is expected to favour local retention of early life stages. Here, we studied the distribution of cod eggs along inshoreoffshore transects in 20 Norwegian fjords. The general pattern exhibited across all fjords was a higher concentration of cod eggs inside the fjords than further offshore. In particular, fjords with shallow sills (model threshold $37 \mathrm{~m}$ ) show an abrupt reduction in egg density over the sill. This study provides empirical support for an offspring retention hypothesis, which may help to explain the maintenance of local population structure in pelagic marine systems.
\end{abstract}

KEY WORDS: Atlantic cod · Gadus morhua $\cdot$ Egg distribution $\cdot$ Population structure

\section{INTRODUCTION}

According to Thorrold et al. (2001), the local population structure of coastal species may result from physical barriers limiting dispersal among habitats behavioural features such as homing of adults to their natal area. It has been proposed that the existence of a highly heterogeneous population structure is inversely proportional to the species dispersal potential (e.g. Waples 1998). However, it is also acknowledged that a prolonged dispersal potential (for example measured by the duration of the mobile early life stages) does not always result in populations that are genetically similar over large distances (e.g. Kettle \& Haines 2006).

Marine organisms face a special challenge in that ocean currents may transport pelagic eggs and larval stages passively over vast distances, potentially moving them toward unfavourable habitats. Indirect evidence for the ecological and genetic impact of larval drift is the observation that many marine species are genetically similar over large geographic distances as compared to terrestrial and freshwater organisms (e.g. Waples 1998, Knutsen et al. 2004). However, recent studies have also revealed that marine species with pelagic early life history stages can be structured into local populations on surprisingly small geographical scales (Campana et al. 1999, Knutsen et al. 2003). Potential mechanisms explaining such local population structure include (1) high site-fidelity of both juveniles and adults, (2) homing of mature individuals to their natal area, and (3) spawning site selection minimising the advection of pelagic offspring. These mechanisms need not be mutually exclusive.

In coastal marine systems, there is evidence supporting the site-fidelity hypothesis (Green \& Wroblewski 2000) and the homing hypothesis (Thorrold et al. 2001). The offspring retention hypothesis has not been fully investigated, particularly in temperate marine systems. Recent modelling work shows that coastal hydrodynamics is potentially important for generating non- 
random dispersal of pelagic early life stages, affecting the balance between gene flow and local adaptation in coastal marine species (Cowen et al. 2006). Innovative field analyses showed evidence for a high degree of self or local recruitment in a variety of coral reef species (Jones et al. 2005), emphasizing the importance of the offspring retention hypothesis. However, coral reef fish species have a relatively short pelagic life cycle when compared to more temperate or subpolar species, and many of them have demersal egg stages. These features alone would not favour a long-distance drift of early life stages. Therefore, it is not yet clear to what extent similar patterns of early life retention and self-recruitment also apply to more temperate species with long-lasting pelagic egg and larval phases.

With regard to more temperate systems, the seminal study of Iles \& Sinclair (1982) on the north Atlantic herring Clupea harengus, also a species with demersal eggs, suggests the existence of local circulation patterns that favour larval retention and the maintenance of population structure across the entire north Atlantic. Bailey et al. (1997) propose similar mechanisms to explain the genetic structure of walleye pollock Theragra chalcogramma, a species with pelagic eggs, across the north Pacific. However, it is in small-scale settings that the existence of local population structure is most intriguing. Ruzzante et al. (1996) has shown that genetic structure is recognizable also within a patch of cod larvae, presumably originating from different local spawning aggregations, but there is no causal explanation of how such structure is generated in first place. Thus, the role of the early life retention hypothesis in relation to small-scale population structure still remains untested, particularly in temperate or subarctic seas.

Here, we study the significance of the egg retention hypothesis for maintaining a local population structure in Norwegian coastal cod by sampling cod eggs in transects of fjords. Sampled habitat types range from sheltered fjord basins inside sills to more open coastal habitats, throughout the western and southern coast of Norway. The Norwegian coastal cod spawn in excess of a million eggs, distributed over multiple spawning events during February-April. The eggs hatch after 2 or $3 \mathrm{wk}$ and the larvae stay in the water column where they feed on zooplankton. The larvae metamorphose and settle in demersal nearshore habitats in early summer (April-June) when they are about 3 to $5 \mathrm{~cm}$ long. The Norwegian Coastal Current (Skjoldal 2004) has the capacity to rapidly mix pelagic eggs and larvae over vast distances. Still, Norwegian coastal cod is composed of local populations, some of which are separated by only a few tens of kilometers (Knutsen et al. 2003), which also differ in adaptive traits such as age and size at maturation (Olsen et al. 2004). Further, tagging studies indicate that the Norwegian coastal cod has a site fidelity compa- rable to the extent of the local populations as inferred from genetic studies (Danielsen \& Gjøsæter 1994).

\section{MATERIALS AND METHODS}

We sampled cod eggs in inshore-offshore transects from 20 fjords along the Norwegian coast during the cod spawning period in March-April 2005 (Fig. 1, Appendix 1 available at: www.int-res.com/articles/suppl/m333 p249_app.pdf). Two of the fjords, Lillesand (18) and Risør (19), were also sampled in March 2004. The eggs where collected with a WP2 plankton net (diameter: $60 \mathrm{~cm}$; mesh width: $500 \mu \mathrm{m}$ ). The net was hauled vertically from $50 \mathrm{~m}$ depth (in shallower waters just above the bottom) to the surface at a speed of $0.5 \mathrm{~ms}^{-1}$, filtering about $14 \mathrm{~m}^{3}$ of water in each tow. This depth range was chosen based on preliminary hauls in all geographic areas (southern, western, and northern Norway) split into vertical depth segments of 75 to 50,50 to 25 and 25 to $0 \mathrm{~m}$; none or very few eggs below $50 \mathrm{~m}$ depth either inside or outside fjords for all areas were detected (H. Knutsen pers. obs.). Cod eggs were identified among the plankton following Russel (1976; see also www.larvalbase.org). Early stage cod eggs cannot readily be distinguished from those of haddock Melanogrammus aeglefinus based on visual inspections of egg size and appearance. Older egg stages of cod and haddock, however, can be distinguished. Among the older stage eggs in our samples only $1 \%$ were identified as haddock (23 out of 2287 cod + haddock eggs). This indicates that haddock eggs were not an important source of bias in the estimates of total cod egg abundance. At each sampling site, we recorded latitude, longitude, bottom depth and the distance to the sill of the fjord.

We tested the effect of local geographic features on egg distribution using different formulations of Generalized Additive Models (GAM; Wood 2006). The response variable $(y)$ was the natural logarithm of egg density (the sum of all stages), standardized by volume filtered. The inspected predictor variables (hereafter covariates) were the natural logarithm of bottom depth $(z$, the logarithm was taken to achieve a uniform distribution of sampling depths), distance in meters from the sampling station to the sill location $(d)$, depth $(s)$ and latitude (l) of the sill. The distance from the sill was negative if the sampling station was inside of the sill and positive otherwise. Only tows located at less than $10 \mathrm{~km}$ from the sill (either side) and with positive egg count were included in the analysis. Removal of tows outside of the $10 \mathrm{~km}$ range ( 7 out of 233) was necessary to reach a uniform spread of samples on either side of the sill. Removal of zero-egg tows (9 out of 233) was necessary to stabilize the variance and normalize the distribution. All but one of the discarded zero-egg 


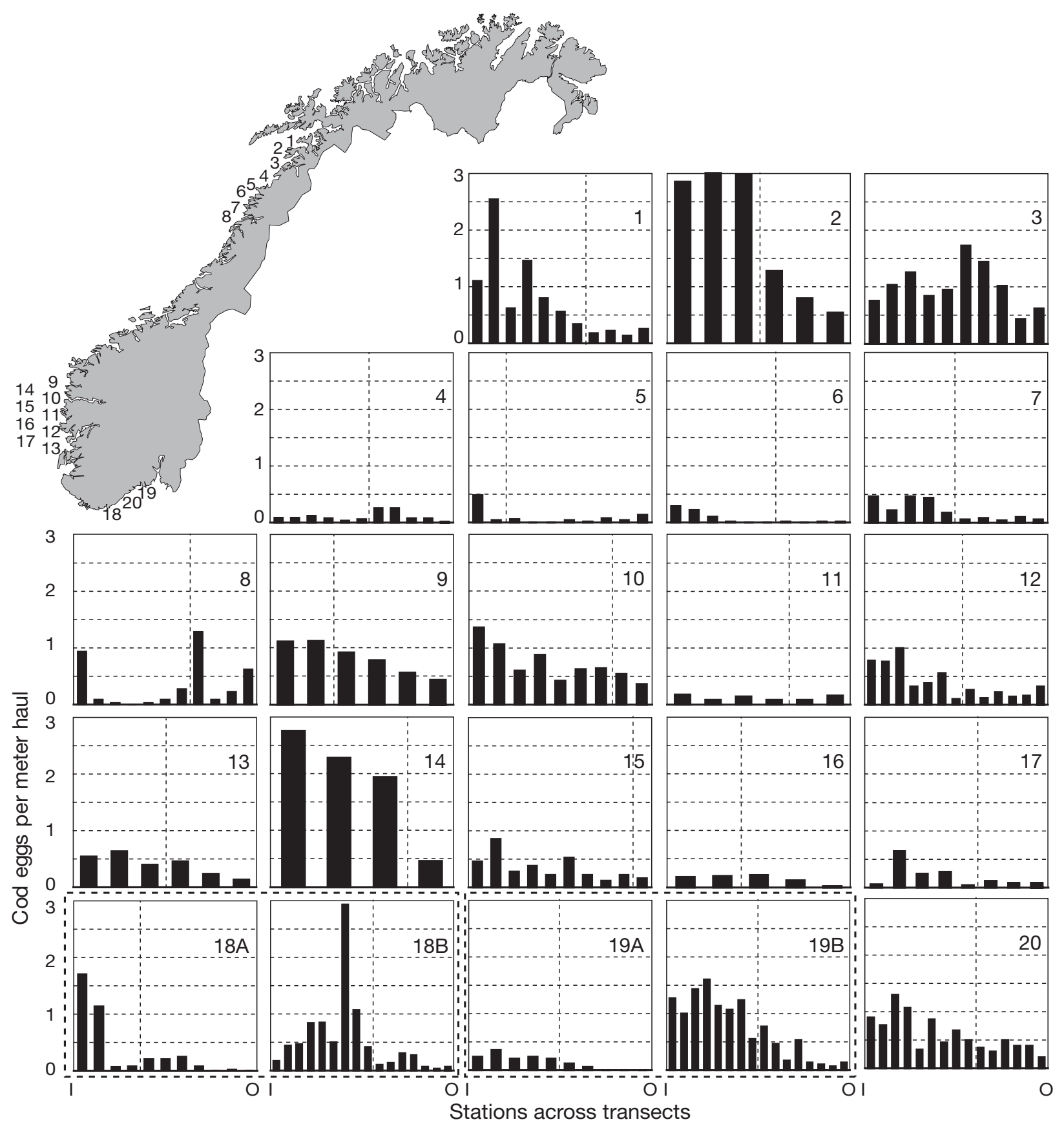

Fig. 1. Gadus morhua. Raw data showing number of eggs $\mathrm{m}^{-1}$ haul in transects from 20 fjords in Norway. Stations arranged on $X$-axis from innermost (I) to outermost (O) station in transect. Vertical dotted lines: location of sill for each fjord. Transects-North Norway: (1) Hopen, (2) Reipå, (3) Bjerangsfjorden, (4) Storfjorden, (5) Okfjorden, (6) Sørfjorden, (7) Brekosen, (8) Beiarnfjorden; west Norway: (9) Landviksosen, (10) Hellosen, (11) Fanafjorden, (12) Kolltvettosen, (13) Davængvågen, (14) Lurosen, (15) Austerfjorden, (16) Skogsvågen, (17) Lysefjorden; south Norway: (18A,B) Lillesand in 2004 and 2005, respectively; (19A,B) Risør in 2004 and 2005, respectively, (20) Tvedestrand. NB the vessel was prevented from entering the area on the fjord side of the sill in Bjerangsfjorden (Transect 3). See Appendix 1 for detailed maps

samples were located offshore of the sill, while one sample, in Beiarnfjorden (8), was located about $10 \mathrm{~km}$ outside of the sill. This fjord was rather unique, in that it was very long and with a very shallow sill $(6 \mathrm{~m})$. The egg distribution pattern along this fjord will be dealt in greater detail in the 'Results' and 'Discussion'. The final number of stations used in the data set was 217 .

We compared results from 3 different model formulations, each addressing a specific hypothesis (Table 1). In Model 1 (the 'null' model) it is assumed 
Table 1. Generalized Additive Model (GAM) equations used to analyze the Gadus morhua egg distribution data. Model 1 is a fully additive formulation, while Models 2 and 3 are non-additive formulations in which the relationship between egg density $(y)$ and distance from the sill $(d)$ is allowed to change depending on whether the latitude ( $l$, Model 2$)$ and depth ( $s$, Model 3 ) of the sill are above or below a threshold value $(r)$ estimated from the data. $k_{t}$ and $k_{f}$ are year- and fjord-specific constant coefficients, $\varepsilon$ is the error term, assumed to be normally distributed with finite variance and equal among the 2 regimes of Models 2 and 3. The subindices $i$ and $t$ identify the sample and the year, respectively. $z$ is the natural logarithm of bottom depth in meters, and the $g$ s are smooth functions (i.e. natural cubic splines) linking the covariates with the response variable

\begin{tabular}{|lll|}
\hline Model type & Equation & Threshold \\
\hline Model 1 & $y_{i, t}=k_{t}+k_{f}+g_{1}\left(z_{i}\right)+g_{2}\left(d_{i}\right)+\varepsilon_{i}$ & No threshold \\
Model 2 & $y_{i, t}=k_{t}+k_{f}+g_{1}\left(z_{i}\right)+ \begin{cases}g_{2}\left(d_{i}\right)+\varepsilon_{i} & \text { if } l \leq r \\
g_{3}\left(d_{i}\right)+\varepsilon_{i} & \text { otherwise }\end{cases}$ & Latitude \\
Model 3 & $y_{i, t}=k_{t}+k_{f}+g_{1}\left(z_{i}\right)+ \begin{cases}g_{2}\left(d_{i}\right)+\varepsilon_{i} & \text { if } s \leq r \\
g_{3}\left(d_{i}\right)+\varepsilon_{i} & \text { otherwise }\end{cases}$ & Sill depth \\
\hline
\end{tabular}

that the distribution of eggs along a fjord (i.e. relationship between egg density and distance from the sill) is similar across all sampled fjords. This hypothesis is in contrast to those of Models 2 (the 'geographic' effect model) and 3 (the 'sill' effect model), in which the distribution of eggs along a fjord can change according to a threshold value of either the latitude or the depth of the sill, respectively. The selection of the threshold was based on the minimization of the generalized cross validation (GCV) among a variety of GAM models spanning the entire range of possible threshold values. For more details on threshold estimation see Ciannelli et al. (2004). The GCV, although suitable for comparing models having a similar formulation (e.g. models with thresholds), does not properly account for the presence of additional parameters (i.e. the threshold) when comparing models with different formulations. Thus, to properly compare models with and without a threshold, we numerically computed the cross validation score (hereafter referred to as genuine cross validation, $\mathrm{CV}$ ) as follows. A random selection of 20 data points (about $10 \%$ of the entire data set) was excluded from the model calibration. The resulting model was then used to predict these 20 out-of-sample observations, and the mean-squared predictive error was calculated. The operation was repeated 500 times, with the final CV being the mean among the 500 evaluations of the mean-squared predictive error. Low CV values indicate models with better fit to the data and lower complexity.

\section{RESULTS}

The data showed a clear signal where most fjords have a high egg density in inshore stations (inside the sill or at the sill) and with decreasing levels further offshore (cf. Fig. 1, Appendix 1). Beiarnfjorden (8) deviated from the expected pattern. This, could be due to a very shallow entrance sill (6 $\mathrm{m}$ depth), and that the 'outside' of this sill is the inner part of another larger fjord (see Appendix 1 for map details). Other deviating results were the low number of eggs in Storfjorden, Okfjorden and Sørfjorden (Fjords 4, 5 and 6 in Fig. 1). This is probably due to the fact that these 3 fjords were sampled last in the study, when cod spawning was already decreasing. We were not able to sample inside the sill of Bjerangsfjorden (3) as a power line was too low to pass under with the research vessel. Fanafjorden (11) at Hordaland had multiple deep sills and the shallowest one was noted.

In agreement with the raw data, all examined model formulations indicate a clear effect of distance from the sill on egg distribution. In Model 1 (i.e. no difference of egg distribution among fjords), the density of eggs reaches a peak slightly inshore of the sill location, and quickly decreases offshore of it (Fig. 2). Results of Model 2 indicate that the effect of distance from the sill vary according the geographic location of the examined fjord. In particular, fjords located south of $60.8^{\circ} \mathrm{N}$ exhibit a constant and linear decline of egg density, going from inshore to offshore locations, while fjords north of $60.8^{\circ} \mathrm{N}$ exhibit a peak of eggs slightly inshore of the sill and a slight decline tapering off to a plateau afterwards (Fig. 3, Appendix 2 available at: www.intres.com/articles/suppl/m333p249_app.pdf). Similarly, results from Model 3 indicate that the egg density in fjords with a sill depth shallower than $37.05 \mathrm{~m}$ reaches a pronounced peak inshore of the sill and a decline offshore of it, while the egg density in fjords with a sill deeper than $37.05 \mathrm{~m}$ constantly decline with the increase in distance from the sill (Fig. 4, Appendix 2). In spite of their similar pattern of egg distribution, southern fjords or fjords with a deep sill constituted 2 different groups (cf. legend of Figs. 2 \& Fig. 3). Based on the $\mathrm{CV}$ score, the 'sill effect' $\left(\mathrm{CV}=0.547, \mathrm{R}^{2}=\right.$ $72.2 \%$ ) model is marginally superior to the 'geographic effect' (GCV $=0.576, \mathrm{R}^{2}=71.7 \%$ ) model, and both superior to the 'null' (GCV $=0.618, \mathrm{R}^{2}=68.7 \%$ ) model. The effect of bottom depth was similar among all 

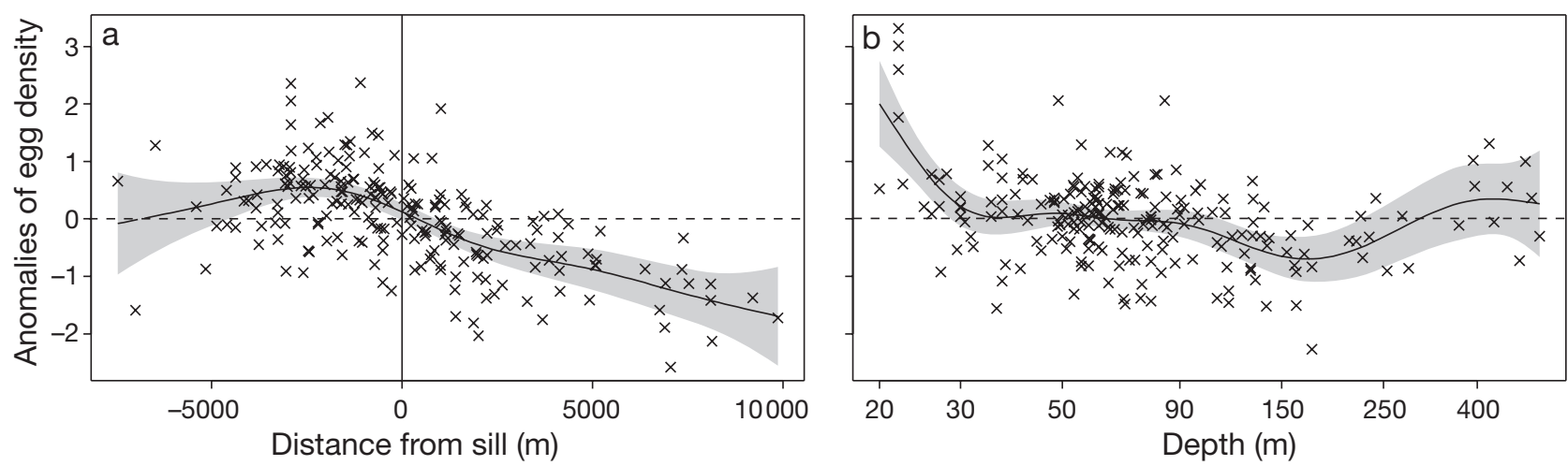

Fig. 2. Gadus morhua. Results from the first model formulation from Table 1 (Model 1, null model). (a) Average effect (solid line) of distance from the sill (negative for stations located inshore of the sill and positive otherwise) on anomalies of egg density. (b) Average effect (solid line) of bottom depth (natural log transformed). Shaded regions indicate the point-wise $95 \%$ CIs around the predicted effect; scatterplots are the partial residuals (i.e. those obtained from a model which includes all the covariates, except that being examined) around the average effect. Horizontal dashed lines indicate the 'zero-effect' response and the vertical line in (a) indicates the location of the sill. The model predicted values are given by the sum of the 2 additive effects plus the fjords- and year-specific coefficients $\left(k_{f}\right.$ and $k_{t}$ from Table 1$)$

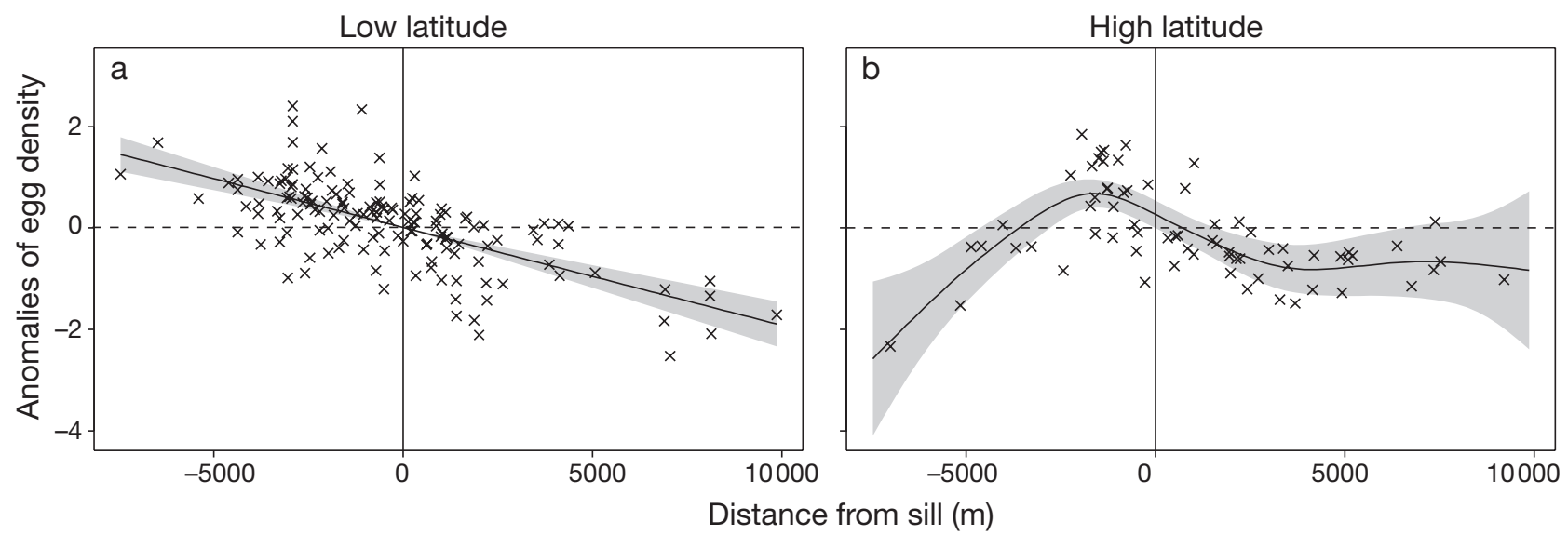

Fig. 3. Gadus morhua. Results from the second model formulation from Table 1 (Model 2, geographic effect). Average effect along with the partial residuals of distance from the sill on anomalies of egg density, for fjords located (a) south and (b) north of $60.8^{\circ} \mathrm{N}$, respectively. See Fig. 2 legend for further details. Fjords north of the latitude threshold were: $1-8$. Fjords south of the latitude threshold were: 9-20

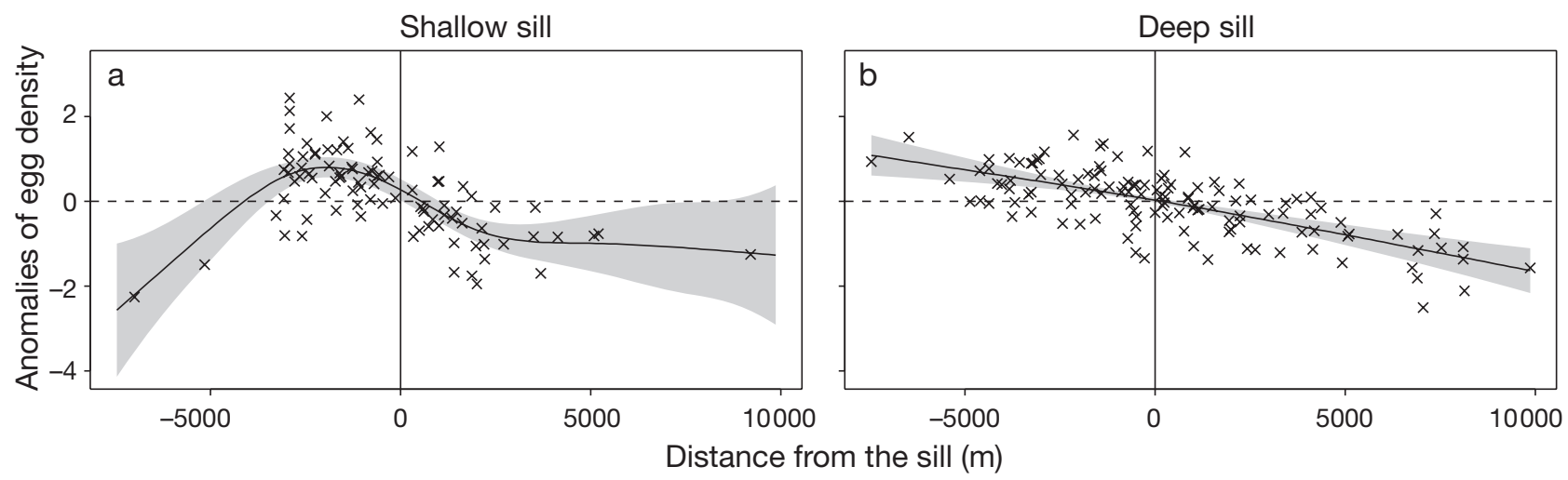

Fig. 4. Gadus morhua. Results from the third model formulation from Table 1 (Model 3, geographic effect). Average effect along with the partial residuals of distance from the sill on anomalies of egg density, for fjords having a sill depth (a) shallower or (b) deeper than $37.05 \mathrm{~m}$, respectively. See Fig. 2 legend for further details. Fjords with a sill depth shallower than the threshold were:

$1,2,7,8,10,18$ and 20. Fjords with sill depth deeper than the threshold were: $3,4,5,6,9,11,12,13,14,15,16,17$ and 19 
model formulations and here it is shown only for the null model (Fig. 2). From visual inspection of the residuals, none of the models showed any heteroscedasticity or strong departure from normality.

\section{DISCUSSION}

This study demonstrates a pattern with a higher density of pelagic eggs in sheltered fjord habitats along the Norwegian coast, and decreasing levels offshore. The fjord sill, i.e. the bottom topography, plays a significant role in determining the spatial pattern of egg distribution. Higher concentrations of eggs are found inside the sill, where the depth of the sill is also of importance. Fjords with shallow sills (model threshold of $37 \mathrm{~m}$ ) show an abrupt reduction in egg density over the sill.

A pattern of higher egg densities within fjords could be the results of (1) adult cod selecting sheltered sections of the fjord for spawning and eggs being retained and/or transported further inwards; (2) adult cod spawning outside the fjord and eggs and larvae being transported inside. The typical estuarine circulation found in most Norwegian fjords transports the surface water out the fjords and the water layer beneath the wind-driven water inwards (Farmer et al. 1983). The buoyancy of the eggs of Norwegian coastal cod (Vikebø 2005) indicate that these will mainly stay below the less saline surface waters, although egg buoyancy may vary considerably among local populations and will also depend on egg volume and whether the egg is spawned early or late in the season (Kjesbu et al. 1992). Also, cod eggs tend to occur at greater depths as egg development progresses (Ouellet 1997), which could increase the retention probability of eggs as they may be located deeper than the sill depth. For comparison, spawning upstream of nursery grounds is well documented for oceanic migratory cod (Bergstad et al. 1987), potentially reflecting an adaptive use of ocean hydrodynamics.

We have direct observations of spawners and nonspawners in one fjord, Tvedestrand, where from a total of 314 coastal cod, 77 to $90 \%$ were mature inside the fjord, whereas $33 \%$ were mature in the outer more exposed part of the fjord (H. Knutsen pers. obs.). Inshore spawning of cod has also been observed elsewhere (Green \& Wroblewski 2000). An alternative explanation is that advection from the offshore would facilitate a high egg/larval drift among neighbouring fjords, which is not supported by genetic data which indicates limited contact among fjords (Knutsen et al. 2003).

Although the highest egg densities were consistently found in the inshore sections of the sampled fjords, some eggs where also found offshore. This raises the interesting question of where these offshore eggs originate. No firm conclusion can be reached from the data available in our study; however, it is still worthwhile to discuss some potential mechanisms. The origin of offshore eggs most likely differs for the different regions sampled. In southern Norway, the eggs found offshore may have been transported from the inshore locations due to occasional events of reverse estuarine fjord circulation in the typical fjord circulation. Alternatively, offshore eggs in southern fjords may have originated in the North Sea, having been entrained in the fast coastal flow (Knutsen et al. 2004, Stenseth et al. 2006), or they may have been the result of some limited offshore spawning of costal cod. In northern Norway, the model depicts a slightly different picture in that the egg density stabilises at a plateau outwards, and does not further decrease. This is expected, as oceanic migratory Arcto-Norwegian cod are present in this northern area and spawn in offshore locations. These cod have a life-history strategy of performing long spawning migrations from the Barents Sea and south along the Norwegian coast, where they spawn. Because the eggs float (Sars 1879), they are exposed to the strong ocean currents in this region which transport them towards the nursery areas in the Barents Sea.

We found a consistent picture of an increase in egg density in both very shallow and very deep stations. The depth pattern should be interpreted as a residual effect, after accounting for distance from the sill. Although there is a correlation between distance from the sill and bottom depth (i.e. deeper offshore), not all fjords have the same length-depth profile. Hence, the depth variable still conveys important information in the analysis. We interpret the higher egg density in shallow and deep stations as a result of higher than average spawning activity of either the coastal (in shallow stations) or the offshore cod populations (in deep stations), respectively. For stations $<50 \mathrm{~m}$ deep there could also be a direct sampling effect. This is because egg density was pooled for the upper $50 \mathrm{~m}$ of the water column while the distribution of eggs is unlikely to be homogeneous within this column. If the eggs are concentrated in the upper parts of the water column, then the density of eggs (given as eggs $\mathrm{m}^{-1}$ haul) will tend to be higher for shallow stations where $<50 \mathrm{~m}$ of water could be sampled.

In most fjords, egg sampling was limited to one spawning season; however, both abiotic and biotic conditions vary among years. Nevertheless, the general pattern of egg distribution was visible throughout a large geographic area, covering major parts of the Norwegian coast, suggesting that the biological signal we describe is an important one. The egg samples from 
a second spawning season from 2 of the fjords also supported the general picture of decreasing egg density along an inshore offshore transect.

In conclusion, we find a pattern with higher density of cod eggs within sheltered fjord basins in keeping with the previously detected genetic structure of adult individuals (Knutsen et al. 2003). The genetic structure in Norwegian coastal cod among fjords is small, but significant, meaning that demographically more or less independent populations exist. In order to get such a genetic effect, egg/larval drift among fjords is most likely also impeded, as only a small level of gene flow would erase such a genetic pattern (cf. Waples 1998). This is not to say that egg/larval drift among fjord does not occur, only that there are strong natural forces acting to retain the early life stages. The present study thus provides evidence for one mechanism which can generate a small-scale population structure, even in temperate species with a long early-life drift phase. However, more data is still needed to determine the origin of the genetic structure in Norwegian coastal cod. We need to learn more about egg distribution in relation to local currents throughout the spawning season. Furthermore, genetic or otolith microchemistry analyses on egg and larval samples from different locations along the fjord will help untangle questions about the spawning origin of these specimens. Finally, the fate (i.e. survival) of the eggs and larvae found inshore compared to those found further offshore is still unknown.

Acknowledgements. We thank the staff at the Institute of Marine Research, Flødevigen Institute of Marine Research (IMR), for assistance with sampling and laboratory analyses. The Norwegian Research Council, and the Norwegian Ministry of Fisheries and Coastal Affairs supported this work. L.C. was supported by funding from the European Union (EU, Marie Curie Fellowship). Comments from Kevin Bailey and Mike Canino improved an earlier draft of this article.

\section{LITERATURE CITED}

Bailey K, Stabeno MPJ, Powers DA (1997) The role of larval retention and transport features in mortality and potential gene flow of walleye pollock. J Fish Biol 51(Suppl A): 135-154

Bergstad OA, Jørgensen T, Dragesund O (1987) Life history and ecology of the gadoid resources of the Barents Sea. Fish Res 5:119-161

Campana SE, Chouinard GA, Hanson JM, Frechet A (1999) Mixing and migration of overwintering Atlantic cod (Gadus morhua) stocks near the mouth of the Gulf of St. Lawrence. Can J Fish Aquat Sci 56:1873-1881

Ciannelli L, Chan KS, Bailey KM, Stenseth NC (2004) Nonadditive effects of the environment on the survival of a large marine fish population. Ecology 85:3418-3427

Cowen RK, Paris CB, Srinivasan A (2006) Scaling of connectivity in marine populations. Science 311:522-527

Danielssen DS, Gjøsæter J (1994) Release of 0-group cod,

Editorial responsibility: Howard Browman (Associate Editorin-Chief), Storebø, Norway
Gadus morhua L., on the southern coast of Norway in the years 1986-1989. Aquac Fish Manag 25:129-142

Farmer DM, Freeland HJ (1983) The physical oceanography of fjords. Prog Oceanogr 12:147-220

Green JM, Wroblewski JS (2000) Movement patterns of Atlantic cod in Gilbert Bay, Labrador: evidence for bay residency and spawning site fidelity. J Mar Biol Assoc UK 80:1077-1085

Jones GP, Planes S, Thorrold SR (2005) Coral reef fish larvae settle close to home. Curr Biol 15:1314-1318

Iles TD, Sinclair M (1982) Atlantic herring - stock discreteness and abundance. Science 215:627-633

Kettle JA., Haines K (2006) How does the European eel (Anguilla anguilla) retain its population structure during its larval migration across the North Atlantic Ocean? Can J Fish Aquat Sci 63:90-106

Kjesbu OS, Kryvi H, Sundby S, Solemdal P (1992) Buoyancy variations in eggs of Atlantic cod (Gadus morhua L.) in relation to chorion thickness and egg size: theory and observations. J Fish Biol 41:581599

Knutsen H, Jorde PE, André C, Stenseth NC (2003) Finescaled geographic population structuring in a highly mobile marine species: the Atlantic cod. Mol Ecol 12: 385-394

Knutsen $\mathrm{H}$, André C, Jorde PE, Skogen MD, Thuróczy E, Stenseth NC (2004) Transport of North Sea cod larva into the Skagerrak coastal populations. Proc R Soc Lond B 271: $1337-1344$

Olsen EM, Knutsen H, Gjøsæter J, Jorde PE, Stenseth NC (2004) Life-history variation among local populations of Atlantic cod from the Norwegian Skagerrak coast. J Fish Biol 64:1725-1730

Ouellet P (1997) Characteristics and vertical distribution of Atlantic cod (Gadus morhua) eggs in the northern Gulf of St. Lawrence, and the possible effect of cold water temperature on recruitment. Can J Fish Aquat Sci 54:211-223

Russel FS (1976) The eggs and planktonic stages of British marine fishes. Academic Press, London

Ruzzante DE, Taggart CT, Cook D, Goddard SV (1996) Genetic differentiation between inshore and offshore Atlantic cod (Gadus morhua) off Newfoundland: microsatellite DNA variation and antifreeze level. Can J Fish Aquat Sci 53:634-645

Sars GO (1879) Indberetninger til Departementet for det Indre fra Dr. G. O. Sars om de af ham i aarene 1864-1878 anstillede undersøgelser angaaende saltvandsfiskerierne. (in Norwegian)

Sinclair M (1989) Marine populations: an essay on population regulation and speciation. University of Washington Press, Seattle, WA

Skjoldal HR (2004) The Norwegian Sea ecosystem. Tapir Academic Press, Trondheim

Stenseth NC, Jorde PE, Chan KS, Hansen E, Knutsen $\mathrm{H}_{\text {, }}$ André C, Skogen MD, Lekve K (2006) Ecological and genetic impact of larval drift. Proc R Soc Lond B 273: 1085-1092

Thorrold SR, Latkoczy C, Swart PK, Jones CM (2001) Natal homing in a marine fish metapopulation. Science 291:297299

Vikebø FB (2005) The impact of climate on early stages of Arcto-Norwegian cod - a model approach. PhD thesis, University of Bergen

Waples RS (1998) Separating the wheat from the chaff: patterns of genetic differentiation in high gene flow species. J Hered 89:438-450

Wood SN (2006) Generalized additive models: an introduction with R. Chapman \& Hall, Boca Raton, FL

Submitted: May 24, 2006; Accepted: August 18, 2006

Proofs received from author(s): March 1, 2007 